\title{
Managing Encephalopathy in the Outpatient Setting
}

\author{
${ }^{1}$ Tarana Gupta, ${ }^{2}$ Sahaj Rathi, ${ }^{2}$ Radha K Dhiman
}

\begin{abstract}
In cirrhosis of liver, hepatic encephalopathy (HE) has an important impact on health-related quality of life. It is important to define whether HE is episodic, recurrent, or persistent; types A, B, or C; overt HE or covert HE; and spontaneous or precipitated. The overt HE is clinically evident and needs hospitalization. Nonabsorbable disaccharides, rifaximin, and probiotics are proven to be useful in the treatment of overt HE. Covert HE includes both minimal HE and grade I HE. It is not apparent on routine clinical examination. Presence of poor work productivity, increased accidental injuries on complex machinery and driving, etc., raise the suspicion of cognitive dysfunction. Specialized neurocognitive testing like psychometric HE, computerized tests like critical flicker frequency tests, inhibitory control tests, Stroop encephalopathy tests, and electroencephalography are needed to diagnose overt HE. Various studies have shown lactulose and rifaximin to be useful in overt HE. However, presence of persistent and recurrent HE in cirrhosis is an indication for liver transplant. Lactulose is effective both in improving reversal of minimal $\mathrm{HE}$ and in reducing the risk of development of overt HE.
\end{abstract}

Keywords: Cirrhosis, Hepatic encephalopathy, Minimal hepatic encephalopathy, Neurocognitive testing.

How to cite this article: Gupta T, Rathi S, Dhiman RK. Managing Encephalopathy in the Outpatient Setting. Euroasian J Hepato-Gastroenterol 2017;7(1):48-54.

Source of support: Nil

Conflict of interest: None

Copyright and License information: Copyright $\odot$ 2017; Jaypee Brothers Medical Publishers (P) Ltd. This work is licensed under a Creative Commons Attribution 3.0 Unported License. To view a copy of this license, visit http://creativecommons.org/licenses/by/3.0/

\section{INTRODUCTION}

Hepatic encephalopathy (HE) is a frequent and one of the most devastating complications of cirrhosis of liver and acute hepatitis. It is compounded by its tendency toward recurrence and persistence of cognitive decline with each episode. This progressive cognitive decline becomes really challenging and exhaustive to manage. The lack of consistency and universally accepted standards in defining HE have caused the investigators to include a wide spectrum of cognitive dysfunction into HE; now terms like covert HE and overt HE have been introduced. ${ }^{1}$ Over the years, with the advent of new therapies and drugs, there is significant advancement in the management of HE with better outcomes. The latest studies support the evidence that encephalopathy in cirrhosis is multifactorial, relating to ammonia metabolism, portosystemic shunting, systemic inflammation, and neuroinflammation. Emerging role of antibiotics and probiotics in addition to traditional lactulose therapy also emphasizes this fact. ${ }^{2}$

\section{DEFINITION OF HE}

Hepatic encephalopathy is a brain dysfunction caused by liver dysfunction and/or portosystemic shunting, which manifests as a wide spectrum of neurological or psychiatric abnormalities ranging from subclinical alterations to coma. ${ }^{1}$

\section{CLASSIFICATION OF HE}

The HE in cirrhosis needs to be classified accurately for selection of appropriate therapy. The following four points need to be addressed in each case.

1. Underlying disease

- Type A: Caused by acute liver failure

- Type B: Caused by portosystemic shunting

- Type C: Caused by decompensated cirrhosis and liver cell dysfunction

2. Time course and duration

- Episodic HE: Occurring once in more than 6 months

\footnotetext{
${ }^{1}$ Department of Medicine, Pandit Bhagwat Dayal Sharma Post Graduate Institute of Medical Sciences, Rohtak, Haryana, India ${ }^{2}$ Department of Hepatology, Postgraduate Institute of Medical Education \& Research, Chandigarh, India
}

Address reprint requests to: Radha K Dhiman, Department of Hepatology, Postgraduate Institute of Medical Education \& Research Chandigarh, India, e-mail: rkpsdhiman@hotmail.com 
- Recurrent HE: Episodes occurring in less than 6 months

- Persistent HE: In between the episodes, there is persistence of behavioral disturbances

3. Precipitating factors

- Spontaneous: No precipitating event

- Precipitated: Precipitant event(s) such as infection, constipation, upper gastrointestinal bleed, electrolyte disturbances, diuretic overdose, etc., are present.

4. Severity of manifestations

- Covert HE: It includes minimal and West Haven grade I HE

- Overt HE: It includes West Haven grade II-IV HE

\section{BURDEN OF DISEASE}

Due to subjective assessment of symptoms and heterogeneity of definitions in various studies, there is variation in reported prevalence of HE. However, overt HE is present in 16 to $21 \%$ in decompensated cirrhosis and 10 to $50 \%$ in posttransjugular intrahepatic protosystemic shunting (TIPSS). ${ }^{3}$ Overall, 20 to $80 \%$ of patients with cirrhosis of liver have either minimal HE or covert $\mathrm{HE}$ at some point during the course of their illness. ${ }^{4}$ Sharma et $\mathrm{al}^{5}$ found a minimal hepatic encephalopathy (MHE) prevalence of $53 \%$ in cirrhosis with $43 \%$ in Child A, 59\% in Child B, and $62 \%$ in Child C patients. Patients with a single episode of overt HE were found to have 1-year cumulative risk of $40 \%$ for recurrent overt $\mathrm{HE}$, and patients with recurrent overt HE had a cumulative risk of $40 \%$ to develop another episode of overt HE within 6 months despite being on lactulose therapy. ${ }^{6}$

\section{CLINICAL PRESENTATIONS}

\section{Overt HE}

Overt HE may present as lethargy or apathy, disorientation for time, increased daytime sleepiness with altered sleep-wake cycle, obvious personality change, inappropriate behavior, dyspraxia or flapping tremor in the initial stage to somnolence, semistuporous, and confused state with gross disorientation. On physical examination, patients may have ataxia, increased deep tendon reflexes, and Babinski's sign. The West Haven Criteria are gold standards for the diagnosis of overt HE. In patients with altered consciousness, the Glasgow coma scale is used for clinical assessment.

\section{Covert HE}

Covert HE consists of minimal HE and grade I HE. It may be completely asymptomatic or may have trivial symptoms. The clinical suspicion is raised in patients with symptoms of euphoria, anxiety, shortened attention span, and impairment of addition or subtraction ability. Patients have history of repeated accidents, traffic rule violations, and driving disabilities resulting from poor attention span, impaired visuomotor coordination, and increased reaction time. ${ }^{7}$ Cognitive function decline and poor work productivity and performance may lead to loss of job and position. Patients with grade I HE have higher mortality than patients without HE. ${ }^{8}$

\section{DIAGNOSIS OF MHE}

The diagnosis of overt HE is made based on history and clinical examination, whereas MHE may be apparent only on specific neurocognitive testing (Table 1). The presence of subtle clinical features raises the suspicion and these patients should be assessed with mini mental state examination (MMSE). An MMSE score $>24$ practically rules out the possibility for overt cognitive impairment, and these patients may be subjected to neurocognitive testing.

The psychometric hepatic encephalopathy score (PHES) consists of five tests. ${ }^{9}$ These are number connection tests $A$ and $B$, line tracing test, serial dotting test, and digit symbol test. For illiterate people, the number connection test may be replaced by figure connection test. ${ }^{10}$ The PHES score may be adjusted for age and education of the concerned patient. The PHES has been validated in many studies and is considered the gold standard in diagnosis of MHE. The drawbacks of PHES are that it is time consuming, needs learning time, and is dependent on age and education.

The newer computerized tests like inhibitory control test (ICT), Stroop test, continuous reaction test, and scan test are easy, quick, and require minimal training. However, they are applicable in only high-functioning patients. The drawback is that they are not validated as PHES score. ${ }^{11}$

In MHE, the electroencephalography (EEG) can reveal slowing of brain activity. The EEG does not require learning abilities and patient cooperation. However, it is expensive and time-consuming.

The critical flicker frequency (CFF) test establishes the ability of brain to detect the flickering of light, which indirectly points toward brain cortical activity. This is an easy, cost-effective test, which is unlike PHES score independent of education. ${ }^{12}$ Romero-Gómez et $a{ }^{13}$ found that CFF $<38 \mathrm{~Hz}$ was predictive for development of further episodes of overt HE in patients of cirrhosis.

The Stroop test assesses the activity of brain to detect color of the word when the semantic meaning of the given word is a different color. It assesses the cognitive function and is available as smartphone application. ${ }^{14}$ Allampati et $\mathrm{al}{ }^{15}$ showed good correlation of Stroop encephalopathy application with PHES score. The ICT is another test for 
Table 1: Tests for diagnosis of minimal HE

\begin{tabular}{|c|c|c|c|c|}
\hline Test & Description & Reliability & Advantages & Disadvantages \\
\hline \multicolumn{5}{|l|}{ Paper-Pencil } \\
\hline PHES & $\begin{array}{l}5 \text { paper and pencil tests number } \\
\text { connection tests } A \text { and } B \text {; digit symbol; } \\
\text { line tracing; serial dotting tests }\end{array}$ & $\begin{array}{l}\text { Sensitivity: } 96 \% \\
\text { Specificity: } 100 \%\end{array}$ & $\begin{array}{l}\text { - Extensively } \\
\text { validated }\end{array}$ & $\begin{array}{l}\text { - Learning effect } \\
\text { - Time consuming } \\
\text { - Good neuromuscular } \\
\text { control needed }\end{array}$ \\
\hline $\begin{array}{l}\text { Repeatable battery } \\
\text { for the assessment of } \\
\text { neuropsychological status }\end{array}$ & $\begin{array}{l}\text { Paper pencil battery testing } 2 \text { domains, } \\
\text { cortical and subcortical }\end{array}$ & Good & $\begin{array}{l}\text { - Has US } \\
\text { reference data }\end{array}$ & $\begin{array}{l}\text { - Copyrighted } \\
\text { - Requires } \\
\text { psychologist }\end{array}$ \\
\hline \multicolumn{5}{|l|}{ Computerized } \\
\hline Inhibition control test & $\begin{array}{l}\text { Presentation of letters at } 500-\mathrm{ms} \\
\text { intervals. Patients instructed to respond } \\
\text { only when } X \text { and } Y \text { are alternating }\end{array}$ & $\begin{array}{l}\text { Sensitivity: } 87 \% \\
\text { Specificity: } 77 \%\end{array}$ & $\begin{array}{l}\text { - Validated } \\
\text { - Does not } \\
\text { require } \\
\text { psychologist }\end{array}$ & $\begin{array}{l}\text { - Requires cooperative } \\
\text { patients } \\
\text { - Requires practice } \\
\text { session }\end{array}$ \\
\hline $\begin{array}{l}\text { Stroop encephalo } \\
\text { application }\end{array}$ & $\begin{array}{l}\text { Identification of the color of symbols or } \\
\text { text presented, while the word names a } \\
\text { different color }\end{array}$ & $\begin{array}{l}\text { Sensitivity: }>70 \% \\
\text { Specificity: } 90 \%\end{array}$ & $\begin{array}{l}\text { - Easy and } \\
\text { quick } \\
\text { - Reliable } \\
\text { - Freely } \\
\text { available }\end{array}$ & $\begin{array}{l}\text { - Cannot be performed } \\
\text { in color-blind }\end{array}$ \\
\hline Scan test & $\begin{array}{l}\text { Computerized digit recognizing task } \\
\text { measuring the reaction times and } \\
\text { errors }\end{array}$ & $\begin{array}{l}\text { Mortality } \\
\text { Hazard ratio: } 2.4 \\
(95 \% \text { confidence } \\
\text { interval } 1.1-5.3)\end{array}$ & $\begin{array}{l}\text { - Reliable, } \\
\text { predicts } \\
\text { mortality }\end{array}$ & $\begin{array}{l}\text { - Need practice } \\
\text { sessions, knowledge } \\
\text { of computer }\end{array}$ \\
\hline \multicolumn{5}{|l|}{ Neurophysiological } \\
\hline $\begin{array}{l}\text { Electroencephalogram and/ } \\
\text { or evoked potentials }\end{array}$ & $\begin{array}{l}\text { Can detect changes in cerebral activity } \\
\text { across the spectrum of } \mathrm{HE}\end{array}$ & $\begin{array}{l}\text { Sensitivity: } \\
\text { 43-100\% }\end{array}$ & $\begin{array}{l}\text { - No learning } \\
\text { effect }\end{array}$ & $\begin{array}{l}\text { - Needs neurologist } \\
\text { - Expensive and labor } \\
\text { intensive }\end{array}$ \\
\hline Critical flicker frequency & $\begin{array}{l}\text { Highest frequency at which the flicker } \\
\text { of a light source can be detected, } \\
\text { above which light is perceived to be } \\
\text { continuous }\end{array}$ & $\begin{array}{l}\text { Sensitivity: } \\
40-100 \% \\
\text { Specificity: } 91 \%\end{array}$ & $\begin{array}{l}\text { - Simple and } \\
\text { reliable } \\
\text { - Uninfluenced } \\
\text { by age, } \\
\text { education }\end{array}$ & $\begin{array}{l}\text { - Requires highly } \\
\text { functioning } \\
\text { patients, binocular } \\
\text { vision, absence of } \\
\text { red-green color } \\
\text { blindness }\end{array}$ \\
\hline Continuous reaction time & $\begin{array}{l}\text { Repeated registration of the motor } \\
\text { reaction time to an auditory stimulus }\end{array}$ & - & - Quick & $\begin{array}{l}\text { - Requires good } \\
\text { hearing }\end{array}$ \\
\hline
\end{tabular}

Modified from Rathi and Dhiman ${ }^{31}$

diagnosis of MHE, and various studies have shown it to be important for prediction of overt HE. ${ }^{16}$

The International Society for Hepatic Encephalopathy and Nitrogen Metabolism (ISHEN) recommends that two different tests should be used to diagnose MHE, which includes one of the tests, which is widely accepted to serve as the comparator. ${ }^{17}$

The upcoming modalities for diagnosis of cognitive dysfunction in cirrhosis are biomarkers and newer imaging tools. The $S 100 \beta$ is an astrocyte protein produced after brain injury and found to be elevated in cirrhosis with MHE/overt HE as compared with healthy subjects. ${ }^{18}$ The lipid peroxidation and increased oxidative stress with synergistic effects in presence of hyperammonemia have also been implicated in pathogenesis of MHE. GimenezGarzó et $\mathrm{al}^{19}$ found correlation of malondialdehyde and 3-nitrotyrosine activity with cognitive decline in cirrhosis. The newer imaging modalities like diffusion tensor imaging and voxel-based morphometry have been used for detecting MHE; however, the data are limited and need further validation.

\section{TREATMENT OF HE IN THE OUTPATIENT SETTING}

\section{Overt HE}

The overt HE includes HE grades II to IV. The primary prophylaxis of overt HE is not routinely indicated except in cirrhosis with high risk to encephalopathy. The overt $\mathrm{HE}$ is most commonly precipitated due to infection, upper gastrointestinal bleed, electrolyte disturbances, constipation, etc., and treating the specific cause with antibiotics, bleed control, and correction of electrolytes and laxatives improves the encephalopathy. The spontaneous or precipitated overt HE needs to be treated with specific antihepatic coma measures. These are as described in Table 2 and Flow Chart 1.

\section{Nonabsorbable Disaccharides}

The lactulose is the mainstay of HE therapy. The lactulose is a synthetic disaccharide, which is undigested in small intestine and reaches the colon, where it is fermented. On fermentation, it acidifies the colonic environment 
Managing Encephalopathy in the Outpatient Setting

Table 2: Agents used in outpatient treatment of HE

\begin{tabular}{|c|c|c|c|c|c|}
\hline \multirow[b]{2}{*}{$\begin{array}{l}\text { Therapeutic } \\
\text { modality }\end{array}$} & \multirow[b]{2}{*}{ Mechanism } & \multicolumn{3}{|c|}{ Role } & \multirow[b]{2}{*}{ Comments } \\
\hline & & Covert HE & $\begin{array}{l}\text { Secondary } \\
\text { prophylaxis of } \\
\text { overt } H E\end{array}$ & $\begin{array}{l}\text { Primary } \\
\text { Prophylaxis } \\
\text { of overt HE }\end{array}$ & \\
\hline Lactulose & $\begin{array}{l}\text { Osmotic laxative } \\
\text { Acidification of the colon } \\
\downarrow \text { Urease-producing bacteria } \\
\downarrow \text { Ammonia production } \\
\downarrow \text { Ammonia absorption }\end{array}$ & $\begin{array}{l}\text { Improved cognitive } \\
\text { function, driving } \\
\text { performance } \\
\text { Cost-effective in } \\
\text { preventing accidents }\end{array}$ & $\begin{array}{l}\text { Most extensively } \\
\text { studied } \\
\downarrow \text { progression to } \\
\text { overt HE }\end{array}$ & $\begin{array}{l}\downarrow \text { likelihood } \\
\text { of overt HE }\end{array}$ & $\begin{array}{l}\text { Mainstay of HE } \\
\text { treatment and } \\
\text { prophylaxis } \\
\text { Cost-effective }\end{array}$ \\
\hline Rifaximin & $\begin{array}{l}\downarrow \text { Urease-producing bacteria } \\
\downarrow \text { Ammonia production }\end{array}$ & $\begin{array}{l}\text { Improves cognitive } \\
\text { function, QOL }\end{array}$ & $\begin{array}{l}\downarrow \text { breakthrough } \mathrm{HE}, \\
\text { hospitalization }\end{array}$ & Not studied & $\begin{array}{l}\text { Modulates flora } \\
\text { Does not cause } \\
\text { resistance }\end{array}$ \\
\hline Probiotics & Improve dysbiosis & $\begin{array}{l}\text { Improvement in } \\
\text { cognitive tests } \\
\text { Improved QOL } \\
\downarrow \text { endotoxins }\end{array}$ & $\begin{array}{l}\downarrow \text { risk of } \\
\text { hospitalization }\end{array}$ & Not studied & $\begin{array}{l}\text { Well tolerated } \\
\text { Available without } \\
\text { prescription }\end{array}$ \\
\hline BCAA & $\begin{array}{l}\text { Promotes the synthesis of } \\
\text { glutamine from ammonia in } \\
\text { skeletal muscle }\end{array}$ & Unclear & $\begin{array}{l}\text { Improves } \\
\text { recurrent HE }\end{array}$ & Not studied & $\begin{array}{l}\text { No effect on } \\
\text { overall mortality }\end{array}$ \\
\hline LOLA & $\begin{array}{l}\text { Ammonia scavenging }-\uparrow \text { pro- } \\
\text { duction of urea in hepatocytes, } \\
\text { activating glutamine synthase in } \\
\text { hepatocytes and skeletal muscle }\end{array}$ & $\begin{array}{l}\text { No improvement in } \\
\text { covert HE } \\
\downarrow \text { progression to overt } \\
\mathrm{HE}\end{array}$ & $\begin{array}{l}\downarrow \text { progression to } \\
\text { overt HE }\end{array}$ & Not studied & $\begin{array}{l}\text { Evidence } \\
\text { conflicting except } \\
\text { in overt } \mathrm{HE} \text {, more } \\
\text { studies needed }\end{array}$ \\
\hline $\begin{array}{l}\text { Glycerol } \\
\text { phenylbutyrate }\end{array}$ & $\uparrow$ Excretion of glutamine & Not studied & $\begin{array}{l}\uparrow \text { time to } \\
\text { recurrence }\end{array}$ & Not studied & $\begin{array}{l}\text { No benefit in } \\
\text { patients on } \\
\text { rifaximin }\end{array}$ \\
\hline Zinc & $\begin{array}{l}\text { If deficient reduce urea cycle } \\
\text { utilization of ammonia }\end{array}$ & $\begin{array}{l}\text { Improvement in } \\
\text { cognitive tests }\end{array}$ & None & Not studied & $\begin{array}{l}\text { No evidence on } \\
\text { other outcomes }\end{array}$ \\
\hline
\end{tabular}

Adapted and modified from Rathi and Dhiman ${ }^{31}$

that supports the growth of beneficial microflora. All these effects lead to decreased ammonia production and absorption. Also, by laxative effect, it decreases the ammonia. Therefore, there is reduction in blood ammonia levels and improvement in cognitive function. It is used for treatment of $\mathrm{HE}$ and for secondary prophylaxis of HE. The lactitol is a newer substance, which has been used in some studies. The nausea and bloating sensation are some side effects. The dose is $25 \mathrm{~mL}$ every 12 hourly until two to three soft stools occur. The dose can be titrated as per patient requirement. A systematic metaanalysis has shown nonabsorbable disaccharides to be useful in the treatment and prevention of HE. ${ }^{20}$ Lactulose is useful in the treatment of HE. Studies have established its role in primary as well as secondary prophylaxis of overt HE.

\section{Rifaximin}

Rifaximin is a semisynthetic, nonabsorbable gut-specific antibiotic. It modulates the gut microbiota and reduces the harmful bacteria. Prolonged use can induce antimicrobial resistance. Bass et $\mathrm{al}^{21}$ showed that rifaximin reduced the episodes of breakthrough HE when compared with placebo (22.1 vs $45.9 \%$ ) over a period of 6 months in patients with chronic liver disease. Rifaximin has a definite role in treatment of HE. In secondary prophylaxis, data suggest its use after second episode of HE (breakthrough episode).

\section{Probiotics}

The probiotics are a new emerging therapy in HE. Probiotics modulate the number and composition of gut microbiota and, therefore, affect the gut brain axis. They reduce the gut-derived toxins and, hence, the ammonia levels. We have previously showed that in patients with cirrhosis who previously had HE there was a significant decline in hospitalizations and complications of cirrhosis, with improvement in the Child-Turcotte-Pugh score and model for end-stage liver disease in probiotic group as compared with placebo. ${ }^{22} \mathrm{~A}$ recent systemic review on probiotics in HE has shown that use of probiotics reverses $\mathrm{MHE}$ and reduces the development of overt $\mathrm{HE}$ as compared with placebo; however, no benefits were found when compared with standard therapy for HE like lactulose, rifaximin, and L-ornithine-L-aspartate (LOLA). ${ }^{23}$

\section{L-ornithine-L-aspartate}

It is a salt of amino acids ornithine and aspartate that helps in urea cycle metabolism and clearance of ammonia. Stauch et $\mathrm{al}^{24}$ showed improvement in the number connection test and blood ammonia level with the use of 
Flow Chart 1: Algorithm for outpatient management of HE; OHE: Overt HE; PSS: Portosystemic shunt. Adapted and modified from Rathi and Dhiman ${ }^{31}$

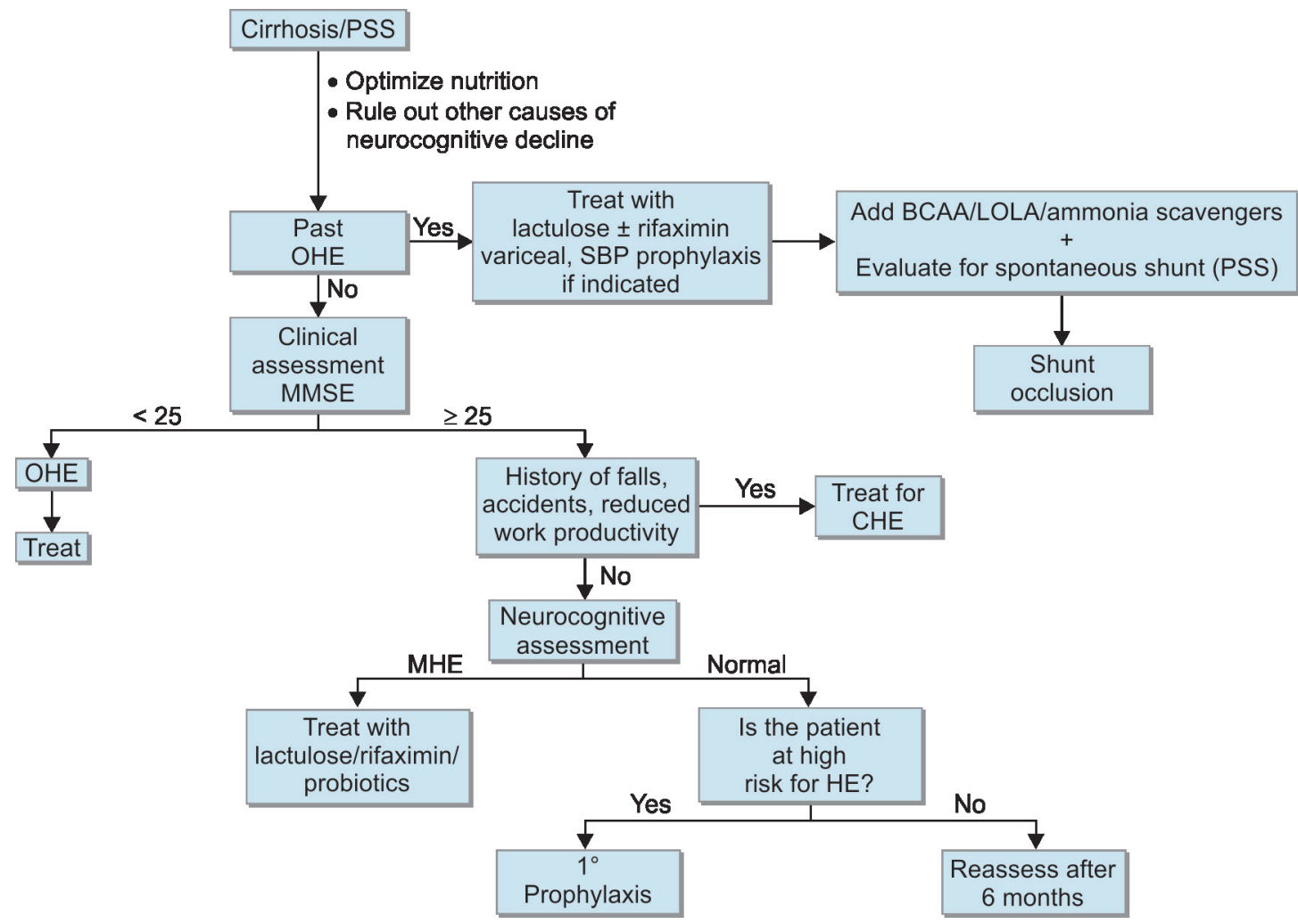

LOLA as compared with placebo in overt HE. The data for LOLA are still conflicting.

\section{Nutrition}

It is very important to understand that cirrhosis is a state of malnutrition. Ammonia clearance occurs through the liver as well as muscle. The sarcopenia associated with cirrhosis leads to reduced ammonia clearance and precipitates HE. Therefore, nutrition is an important target in cirrhosis. The ISHEN recommends 1.2 to $1.5 \mathrm{gm} / \mathrm{kg} /$ day protein and 35 to $40 \mathrm{kcal} / \mathrm{kg} /$ day in cirrhosis. It is preferable to take dairy and vegetable proteins. Patients should be encouraged to consume small, frequent meals. A late night snack rich in energy is helpful in curtailing catabolism due to fasting. ${ }^{25}$ Also, there are data about breakfast improving the cognition. There are data for use of branched chain amino acids in HE; however, long-term efficacy with its use is conflicting.

\section{Shunt Occlusion}

Spontaneous portosystemic shunts, which are enough to divert ammonia directly to systemic circulation, put the patient at risk of developing encephalopathy. Balloon retrograde transvenous occlusion of shunts has shown improvement in symptoms and survival benefits. ${ }^{26}$ Patients with TIPSS and HE may need revision of shunt and reduction in diameter.

\section{Liver Transplant}

In recurrent and chronic persistent $\mathrm{HE}$, with deteriorating liver functions, the medical therapy fails to improve the outcome. Only liver transplant in this situation can help to salvage the patient and improve the outcome.

\section{TREATMENT OF COVERT HE}

Covert HE includes both MHE and grade I HE. Although there are no definite guidelines to treat covert HE, various studies have shown efficacy of different drugs. We showed lactulose therapy to be effective in improving cognitive function and health-related quality of life (HRQOL) in patients of cirrhosis with MHE after 3 months of therapy. ${ }^{27}$ In another study by Sidhu et al, ${ }^{28}$ rifaximin use as compared with placebo showed improvement in cognitive function and HRQOL in patients of cirrhosis with MHE. In chronic persistent subclinical HE, LOLA has shown to improve the psychometric test performance and reduce the blood ammonia levels as compared with placebo in individual studies; ${ }^{29}$ more data are needed for its use. However, there is a need for more data before a clear recommendation about MHE treatment can be made.

We performed a network meta-analysis, ${ }^{30}$ which included 27 randomized controlled trials (RCTs) for reversal of minimal $\mathrm{HE}$ and 21 RCTs to prevent development of overt HE. For reversal of minimal HE, 
rifaximin followed by lactulose, probiotics/lactulose combination, LOLA, prebiotic/probiotic/symbiotic (PPS) combination, and branched chain amino acids (BCAA) were found to be better than placebo or no drug respectively. For prevention of development of overt HE, lactulose, LOLA, and PPS combination was found to be superior to placebo or no intervention. However, rifaximin was not found to be significant in prevention of overt HE. Lactulose is the only intervention found useful in both reversal of minimal HE and prevention of development of overt HE.

\section{PRIMARY PROPHYLAXIS}

Routine use of drugs to prevent episode of overt HE is not recommended. However, cirrhosis with decompensation having high risk of development of HE may be treated with lactulose for primary prophylaxis of overt HE.

\section{CONCLUSION}

In cirrhosis of liver, $\mathrm{HE}$ is a complication, which needs to be addressed immediately, as it has impact on morbidity as well as mortality. Overt HE reduces the work performance, decreases work productivity, impairs the driving ability, and increases the chances of accidental injuries on complex machinery. Its diagnosis through psychometric tests and newer computerized tests is imperative. The role of newer biomarkers and imaging modalities is still in evolution. The lactulose, rifaximin, and probiotics have enough data to consider them as mainstay of therapy. The early stages of encephalopathy are manageable; however, higher grades of HE (grades III and IV) are associated with high mortality. The role of systemic shunting and neuroinflammation needs to be explored further to evaluate newer targets of therapy. In recurrent and persistent $\mathrm{HE}$, only liver transplant can change the natural history of cirrhosis. Finally, lactulose is effective both in improving reversal of minimal $\mathrm{HE}$ and in reducing the risk of development of overt HE.

\section{REFERENCES}

1. Vilstrup H, Amodio P, Bajaj J, Cordoba J, Ferenci P, Mullen KD, Weissenborn K, Wong P. Hepatic encephalopathy in chronic liver disease: 2014 practice guideline by the American Association for the study of liver diseases and the European Association for the study of the liver. Hepatology 2014 Aug;60(2):715-735.

2. Butterworth RF. The liver-brain axis in liver failure: neuroinflammation and encephalopathy. Nat Rev Gastroenterol Hepatol 2013 Sep;10(9):522-528.

3. Nolte W, Wiltfang J, Schindler C, Münke H, Unterberg K, ZumhaschU, Figulla HR, Werner G, Hartmann H, RamadoriG. Portosystemic hepatic encephalopathy after transjugular intrahepatic portosystemic shunt in patients with cirrhosis: clinical, laboratory, psychometric, and electroencephalographic investigations. Hepatology 1998 Nov;28(5):1215-1225.

4. Das A, Dhiman RK, Saraswat VA, Verma M, Naik SR. Prevalence and natural history of subclinical hepatic encephalopathy in cirrhosis. J Gastroenterol Hepatol 2001 May;16(5): 531-535.

5. Sharma P, Sharma BC, Puri V, Sarin SK. Critical flicker frequency: diagnostic tool for minimal hepatic encephalopathy. J Hepatol 2007 Jul;47(1):67-73.

6. Sharma BC, Sharma P, Agrawal A, Sarin SK. Secondary prophylaxis of hepatic encephalopathy: an open-label randomized controlled trial of lactulose versus placebo. Gastroenterology 2009 Sep;137(3):885-891.

7. Wein C, Koch H, Popp B, Oehler G, Schauder P. Minimal hepatic encephalopathy impairs fitness to drive. Hepatology 2004 Mar;39(3):739-745.

8. Patidar KR, Thacker LR, Wade JB, Sterling RK, Sanyal AJ, Siddiqui MS, Matherly SC, Stravitz RT, Puri P, Luketic VA, et al. Covert hepatic encephalopathy is independently associated with poor survival and increased risk of hospitalization. Am J Gastroenterol 2014 Nov;109(11):1757-1763.

9. Weissenborn K, Ennen JC, Schomerus H, Rückert N, Hecker H. Neuropsychological characterization of hepatic encephalopathy. J Hepatol 2001 May;34(5):768-773.

10. Dhiman RK, Saraswat VA, Verma M, Naik SR. Figure connection test: a universal test for assessment of mental state. J Gastroenterol Hepatol 1995 Jan-Feb;10(1):14-23.

11. Weissenborn K. Diagnosis of minimal hepatic encephalopathy. J Clin Exp Hepatol 2015 Mar;5(Suppl 1):S54-S59.

12. Kircheis G, Wettstein M, Timmermann L, Schnitzler A, Häussinger D. Critical flicker frequency for quantification of low-grade hepatic encephalopathy. Hepatology 2002 Feb;35(2):357-366.

13. Romero-Gómez M,Córdoba J,Jover R, DelOlmoJA, RamírezM, Rey R, de Madaria E, Montoliu C, Nuñez D, Flavia M, et al. Value of the critical flicker frequency in patients with minimal hepatic encephalopathy. Hepatology 2007 Apr;45(4): 879-885.

14. Bajaj JS, Thacker LR, Heuman DM, Fuchs M, Sterling RK, Sanyal AJ, Puri P, Siddiqui MS, Stravitz RT, Bouneva I, et al. The Stroop smartphone application is a short and valid method to screen for minimal hepatic encephalopathy. Hepatology 2013 Sep;58(3):1122-1132.

15. Allampati S, Duarte-Rojo A, Thacker LR, Patidar KR, White MB, Klair JS, John B, Heuman DM, Wade JB, Flud C, et al. Diagnosis of minimal hepatic encephalopathy using StroopEncephalApp: a multicenter US-based, norm-based study. Am J Gastroenterol 2016 Jan;111(1):78-86.

16. Gupta D, Ingle M, Shah K, Phadke A, Sawant P. Prospective comparative study of inhibitory control test and psychometric hepatic encephalopathy score for diagnosis and prognosis of minimal hepatic encephalopathy in cirrhotic patients in the Indian subcontinent. J Dig Dis 2015 Jul;16(7):400-407.

17. Bajaj JS, Cordoba J, Mullen KD, Amodio P, Shawcross DL, Butterworth RF, Morgan MY, ISHEN. International Society for Hepatic Encephalopathy and Nitrogen Metabolism (ISHEN). Review article: the design of clinical trials in hepatic encephalopathy - an international society for hepatic encephalopathy and nitrogen metabolism (ISHEN) consensus statement. Aliment Pharmacol Ther 2011 Apr;33(7):739-747.

18. Duarte-Rojo A, Ruiz-Margáin A, Macias-Rodriguez RU, Cubero FJ, Estradas-Trujillo J, Muñoz-Fuentes RM, Torre A. 
Clinical scenarios for the use of S100 as a marker of hepatic encephalopathy. World J Gastroenterol 2016 May;22(17): 4397-4402.

19. Gimenez-Garzó C, Urios A, Agustí A, González-López O, Escudero-García D, Escudero-Sanchis A, Serra MA, GinerDurán R, Montoliu C, Felipo V. Is cognitive impairment in cirrhotic patients due to increased peroxynitrite and oxidative stress? Antioxid Redox Signal 2015 Apr;22(10):871-877.

20. Gluud LL, Vilstrup H, Morgan MY. Nonabsorbable disaccharides for hepatic encephalopathy: a systematic review and meta-analysis. Hepatology 2016 Sep;64(3):908-922.

21. Bass NM, Mullen KD, Sanyal A, Poordad F, Neff G, Leevy CB, Sigal S, Sheikh MY, Beavers K, Frederick T, et al. Rifaximin treatment in hepatic encephalopathy. N Engl J Med 2010 Mar;362(12):1071-1081.

22. Dhiman RK, Rana B, Agrawal S, Garg A, Chopra M, Thumburu KK, Khattri A, Malhotra S, Duseja A, Chawla YK. Probiotic VSL\#3 reduces liver disease severity and hospitalization in patients with cirrhosis: a randomized, controlled trial. Gastroenterology 2014 Dec;147(6):1327-1337.

23. Hörner DV, Avery A, Stow R. The effects of probiotics and symbiotics on risk factors for hepatic encephalopathy: a systematic review. J Clin Gastroenterol 2017;51(4):312-323.

24. Stauch S, Kircheis G, Adler G, Beckh K, Ditschuneit H, Görtelmeyer R, Hendricks R, Heuser A, Karoff C, Malfertheiner P, et al. Oral L-ornithine-L-aspartate therapy of chronic hepatic encephalopathy: results of a placebo-controlled double-blind study. J Hepatol 1998 May;28(5):856-864.

25. Amodio P, Bemeur C, Butterworth R, Cordoba J, Kato A, Montagnese S, Uribe M, Vilstrup H, Morgan MY. The nutritional management of hepatic encephalopathy in patients with cirrhosis: international society for hepatic encephalopathy and nitrogen metabolism consensus. Hepatology 2013 Jul;58(1):325-336.

26. Laleman W, Simon-Talero M, Maleux G, Perez M, Ameloot K, Soriano G, Villalba J, Garcia-Pagan JC, Barrufet M, Jalan R, et al. Embolization of large spontaneous portosystemic shunts for refractory hepatic encephalopathy: a multicenter survey on safety and efficacy. Hepatology 2013 Jun;57(6):2448-2457.

27. Prasad S, Dhiman RK, Duseja A, Chawla YK, Sharma A, Agrawal R. Lactulose improves cognitive functions and health-related quality of life in cirrhotic patients with minimal hepatic encephalopathy. Hepatology 2007 Mar;45(3): 549-559.

28. Sidhu SS, Goyal O, Mishra BP, Sood A, Chhina RS, Soni RK. Rifaximin improves psychometric performance and healthrelated quality of life in patients with minimal hepatic encephalopathy (the RIME Trial). Am J Gastroenterol 2011 Feb;106(2):307-316.

29. Kircheis G, Nilius R, Held C, Berndt H, Buchner M, Görtelmeyer R, Hendricks R, Krüger B, Kuklinski B, Meister $\mathrm{H}$, et al. Therapeutic efficacy of L-ornithine-Laspartate infusions in patients with cirrhosis and hepatic encephalopathy: results of a placebo-controlled, double-blind study. Hepatology 1997 Jun;25(6):1351-1360.

30. Dhiman RK, Thumburu KK, Chopra M, Dutta U, Singh M, Taneja S, Duseja A, Chawla YK. Comparative effectiveness of different pharmacological interventions for the treatment of minimal hepatic encephalopathy: a systematic review with network meta-analysis. Hepatology 2016 Jul;64(Suppl 1):S54.

31. Rathi S, Dhiman RK. Managing encephalopathy in the outpatient setting. Clin Liver Dis 2016 Dec;8(6):150-155. 